\title{
An Analysis of the Correctness of the Data Disclosed in the Land Register and Buildings in the Area of Water Flowing on the Example of Smyków
}

\section{Introduction}

Area of land beneath water in Poland is approximately 649000 ha, which is a little more than $2 \%$ of total area of the country [4]. Despite their limited area, waters are very important to every sector of the economy. It should be marked, that without water, life on Earth would be impossible, which leads to say that water is a public good.

General division of waters in Poland is regulated in the Water Law [6]. More specific division of water according to the aforementioned law is presented on Figure 1.

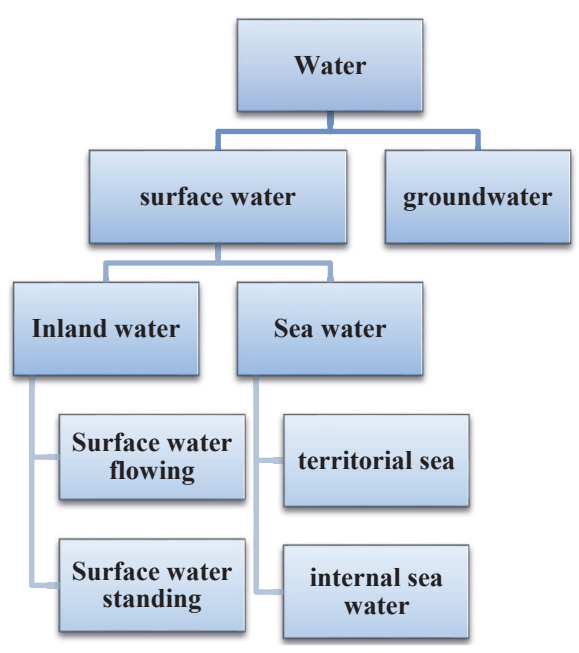

Fig. 1. Division of waters in Poland

Source: own work based on [5]

* AGH University of Science and Technology, Faculty of Mining Surveying and Environmental Engineering, Krakow, Poland 
Waters division is very essential, as it has direct impact on ownership. According to Water Law [6] waters can be divided into public and private. Public waters are property of the State Treasury or counties. Private waters belong to natural people or other legal entities (article 10 of the Water Act [6]).

Public waters belonging to the State Treasury are i.e.:

- territorial sea,

- internal sea water (plus internal sea water of Gdańsk's Harbour),

- inland surface water flowing,

- groundwater.

Other types of water, not mentioned above, can be of private ownership. The author understands them as inland surface water standing or water in trenches.

To sum up, it can be said that ownership of inland surface water standing and water in trenches depends on ownership of the land beneath them. The rest of waters belongs to the State Treasury, independently of ownership of the land beneath them. Of course, surface water standing and water in trenches can belong to the State Treasury, if only they are on land, that belongs to the State Treasury. It can be concluded from this paragraph that only surface water standing and water in trenches can be private water. The rest of the water can be only public water.

Situation gets a little complicated, when surface water flowing are not located on land, which is property of the State Treasury. It is very common, considering that flowing water very often naturally changes its course. In that case, the Water Law comes to help. According to it, "land covered with surface water is property of the water owner" (article 14 section 1 of the Water Act [6]) - so it is water, which decides about ownership of land beneath them, not the other way round [5].

That is why it is so important to determine properly watercourse line during surveys, which is no doubt shoreline. Shoreline becomes property line directly, and so it determines range of ownership rights. Its determination is very fundamental task, because its results have strong influence on ownership rights, which is the strongest of all the rights [3].

Surface water flowing has natural inclination to change its course in time, and so to change property line. It should be highlighted that change of the area of the parcel is consequence of the change of the watercourse. Very often, erosion caused by watercourses, causes clear decrease of the parcels that are located directly by watercourse. It is very important issue, because decrease of area stated in the records can influence change of fees for property [2]. That is why it is important to determine properly watercourse line in the register of land and buildings.

Unfortunately, in many cases, the limit shown in the register of land and buildings does not coincide with that which can be observed in the field. Lines the shore as the boundaries of the property revealed a database of land records and the state register of borders, while its actual course determined by direct measurement in the field is revealed in a database of topographical objects (BDOT500). In practice, very often you can observe lack of consistency between the databases, which leads to 
the fact that the border disclosed in the records does not coincide with the actually occurring in the field [1].

In this article the author wishes to draw attention to the need to demonstrate the correct boundary watercourse report register of land and buildings, pointing to directly examples of its erroneous determination on the example of Smyków.

\section{Subject, Goal and Test Methods}

While working in the field every surveyor met probably once the case where upon arrival at the plot saw on the ground: a stream, river, creek or other natural watercourse, while on the cadastral map was not at all demonstrated. By comparing the cadastral map with orthophotomap it can be noticed that such cases are very many. Each track in a natural way can change its channel, and therefore also lines of the shore. That is why it is very important that the data disclosed in the land records in a way that reflect the actual facts occurring on the lot.

In this paper, using simple and public GIS analyzes the compatibility of the course of borders of water flowing disclosed in land and buildings report of their actual occurrence in the area on the example of Smyków. Municipality Smyków (Fig. 2) is a small, rural village located in the north-western part of the Świętokrzyskie province, which has many tourist advantages. It has a fairly well-developed river network (Fig. 3), therefore it has become a subject of research.

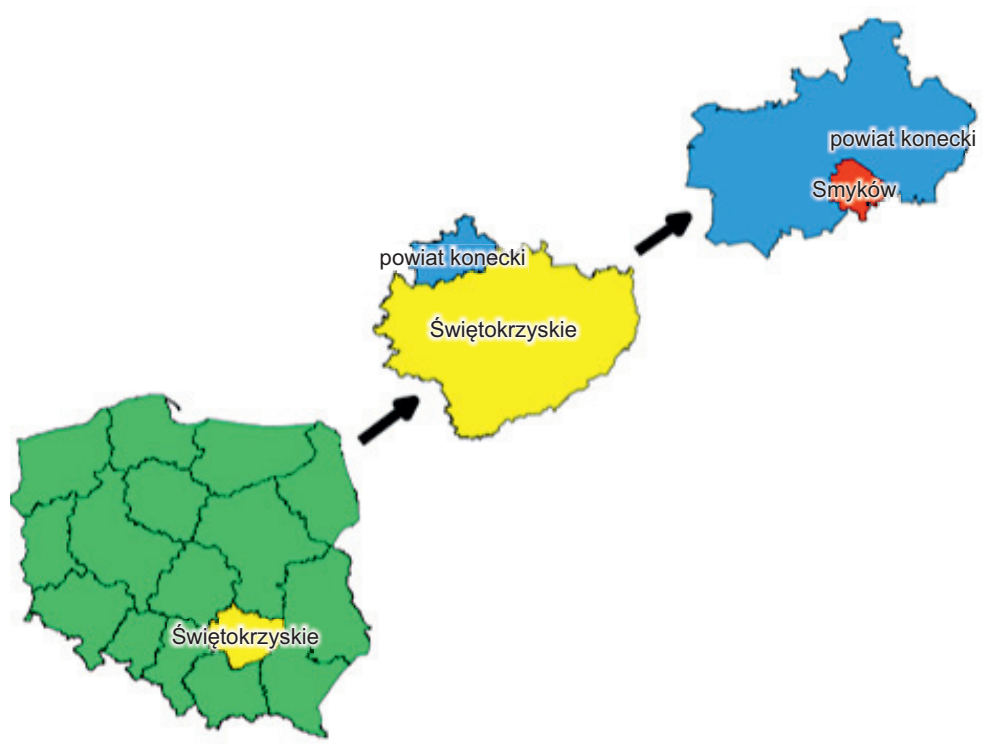

Fig. 2. Location of the Commune Smyków against the territorial division of the country 


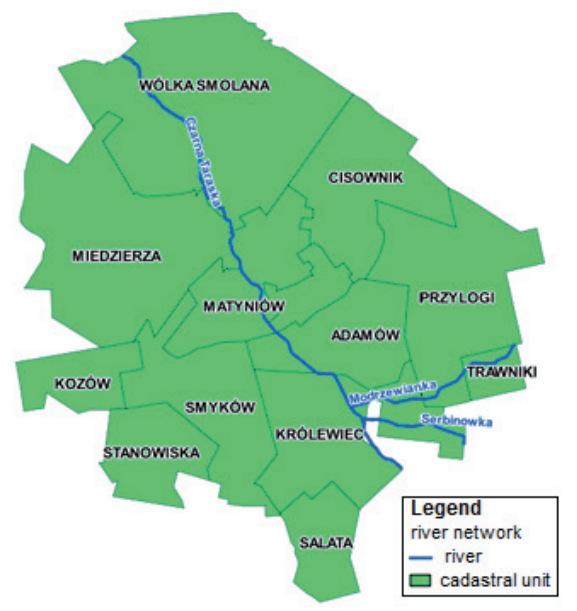

Fig. 3. The network of rivers Municipality Smyków

By the municipality flow three rivers lowland, i.e.: Czarna Taraska, Modrzewianka and Serbinówka. It is divided into 12 precincts registration (Fig. 3). Over 90\% of the area is forest land and agricultural land, now occasionally cultivated. A very small percentage of the area of lands are processed by man. We can conclude that the municipality is the perfect test subject, because of the vast majority of area nature itself shapes the landscape.

\section{A Comparative Analysis of Orthophotos with a Cadastral Map}

In order to check how the situation disclosed in the land records coincides with the reality of their borders courses in the area, a comparison raster cadastral maps with orthophotomap. We analyzed the course of the shoreline of individual natural water courses in each of the 12 precincts cadastral belonging to the municipality Smyków. Mileage border watercourses shown in the database register of land and buildings was determined on the basis of raster cadastral maps, while the actual course of the edge of the area determined on the basis of orthophoto. The following presents the results of the analysis.

\subsection{Examples of Changes in the Shoreline Not Shown on the Cadastral Map}

It was noted that in most cases the limit shown on the cadastral map does not coincide with the actual course of the boundary current (Fig. 4). It was found that the data shown in the register of land and buildings on the borders courses are often out-of-date and in need of modernization. It noted examples of the evident changes in watercourses due to forces of nature, and not updated in the cadastre area of different villages in the municipality of Smyków. 

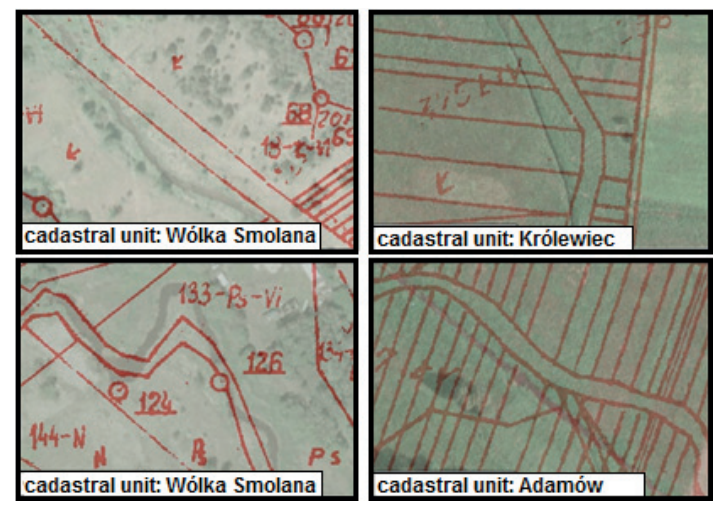

Fig. 4. Examples of changes shoreline not shown on the cadastral map Source: own work based on [7]

\subsection{Examples of Failure to Observe the Continuity of the Stream on the Border of the Registration Precincts}

After a deeper analysis of the orthophoto and cadastral map noticed an interesting relationship, namely the failure to find a few examples of the continuity of the stream at the junction of registration precincts. River draft only to the border precincts (in the framework of a single sheet of cadastral map), while on the sheet next precincts of the river has not been demonstrated, despite the undeniable continuity of the trough, which could be observed in orthophotomap (Fig. 5). This was due to the fact that every cadastral draft on different sheets of cadastral maps. It is an interesting case, because with the overseas precincts ended the river.

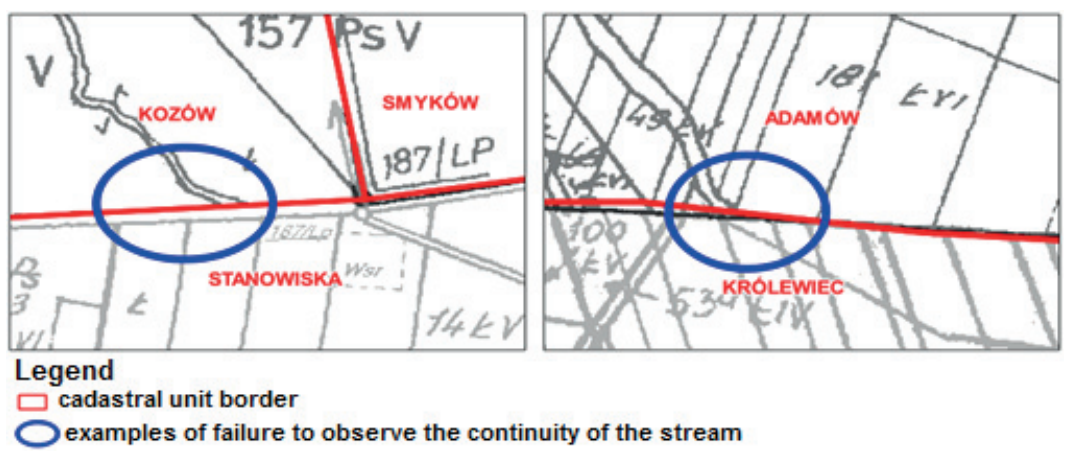

Fig. 5. Examples of failure to observe the continuity of the stream on the border of concessions

Source: own work based on [7] 


\subsection{Examples of Courses Not Appearing on the Cadastral Map}

Comparing the cadastral map of orthophotomap noted that in many cases, despite the clear presence of the watercourse in the area not plotted it on the cadastral map (Fig. 6).

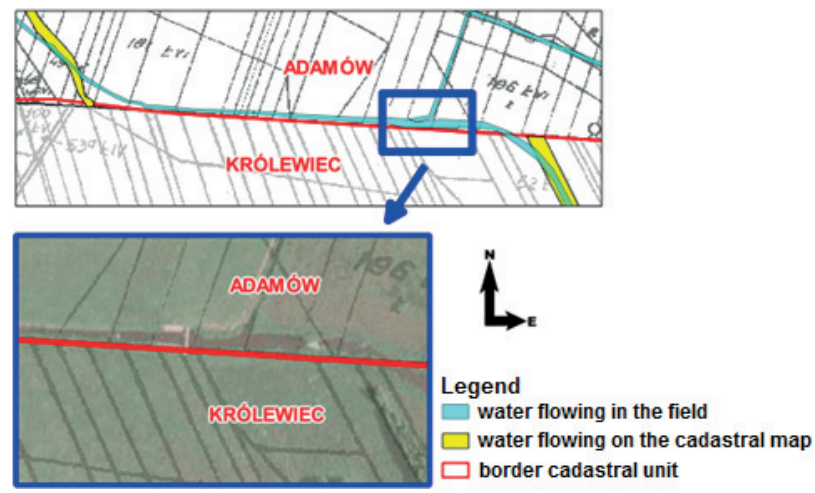

Fig. 6. Example demonstrate the lack of cadastral map flowing water Source: own work based on [7]

\subsection{Examples of Incorrectly Marked on the Map of Land Cadastral}

Very often in the field, you can encounter a situation in which when you arrive at the ground find that the lot is crossed by water flowing or other natural watercourse, while on the cadastral map a ditch is shown. Making a comparative analysis also found such cases.

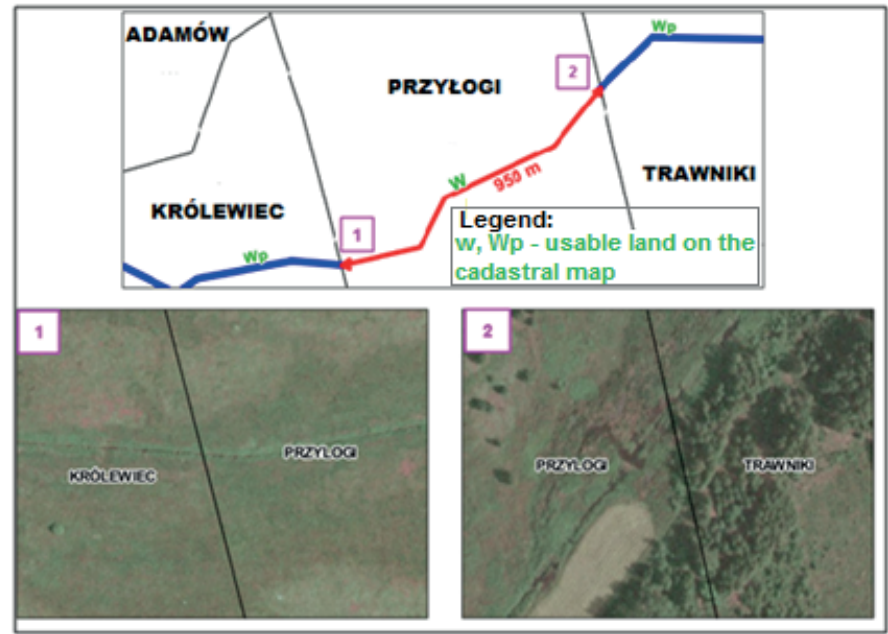

Fig. 7. Example wrongly identified land in the records

Source: own work based on [7] 
On Figure 7 can be seen that the length of approx. $950 \mathrm{~m}$ of the river Modrzewianka in the records it has been shown in the use or ditch. In contrast, evidently it should be revealed as $W_{p}$, that is, the water flowing. At orthophotomap you can see that the boundary between the lands of $W_{p}$ (water flowing) and $W$ (trench) at the end of the two precincts, there is no reflection in the field. Track retains the same characteristics within the limits of the use $W$ and $W_{p}$, thus demonstrating the trench in the records appear to be entirely groundless. In addition, as you can see this is another example confirming the lack of consistency between the data presented on the following map sheets register within individual precincts.

\subsection{Conclusions from the Comparison of Maps}

On the basis of comparative analysis it can be stated that the data presented in register of land and buildings within the municipality Smyków are in many cases not enough to date. It is noted that the limit of the number of courses disclosed cadaster in no way correspond to that which can be seen in the field. It is a very worrying phenomenon, because the line the shore disclosed in the records directly is border of the property. Changing the shore line causes a change in the boundaries of the property adjacent to the river.

Also troubling is that besides little current shoreline happen examples to demonstrate the lack of courses on maps registration. This is an obvious error which results in the fact that after the demarcation of land covered by the waters of the adjacent land and updating of cadastral data, part of the plot occupied by the river with the law itself will become the property of the State Treasury. The legal status of the property is changed.

Another type of errors found in the records is incorrect determination of land on the cadastral map. Very often it happens that the water flowing is recognized as a ditch. According to the Water Law ditch is owned by the owner of the lot, while the area of land occupied by the river is owned by the State Treasury (Fig. 8).

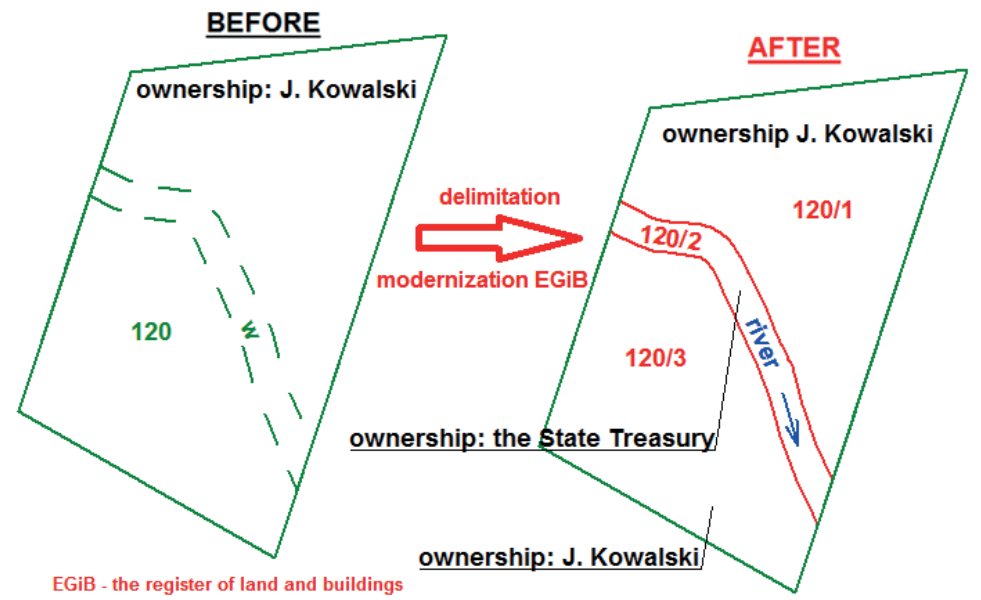

Fig. 8. Legal status after the disclosure of the watercourse on the lot 
In this case, the legal situation that could arise, based on the data disclosed in register of land and buildings would be incorrect.

On these two examples it can be seen that errors in the records may result in the creation of a false real estate legal status. Setting boundaries in the field very often raises a lot of negative emotions. It happens that the owners of lots of land can not accept the changes to the boundaries of their property, which often leads to disputes. Therefore, to avoid this data disclosed in the records should be kept at a constant topicality.

\section{Spatial Analysis Using GIS Tools}

After finding so many inconsistencies, in order to fully investigate the extent of the phenomenon, by using simple and publicly available GIS tools it was tested on how much data records are consistent with the facts trying to identify specific figures.

In the first stage of the study vectorization of all the ditches $(W)$ and flowing waters $\left(W_{p}\right)$ reported on raster maps was made, cadastral divided into precincts registration. Then actual occurrence limits of the same land in the area were determined using orthophoto.

In the next stage, an author calculated surface ditches and water flowing both in the field, as well as shown in the records in each of the individual concessions. Vectorization land and calculation of surface was performed using widely available software QGIS. The calculation results are presented in Figure 9.

Analyzing Figure 9 it can be seen first of all, that the surfaces shown in the records differ significantly from what actually occurs on the ground. Such large differences in the surface seem to be huge, because the ditches and flowing water are characterized by a relatively small width.

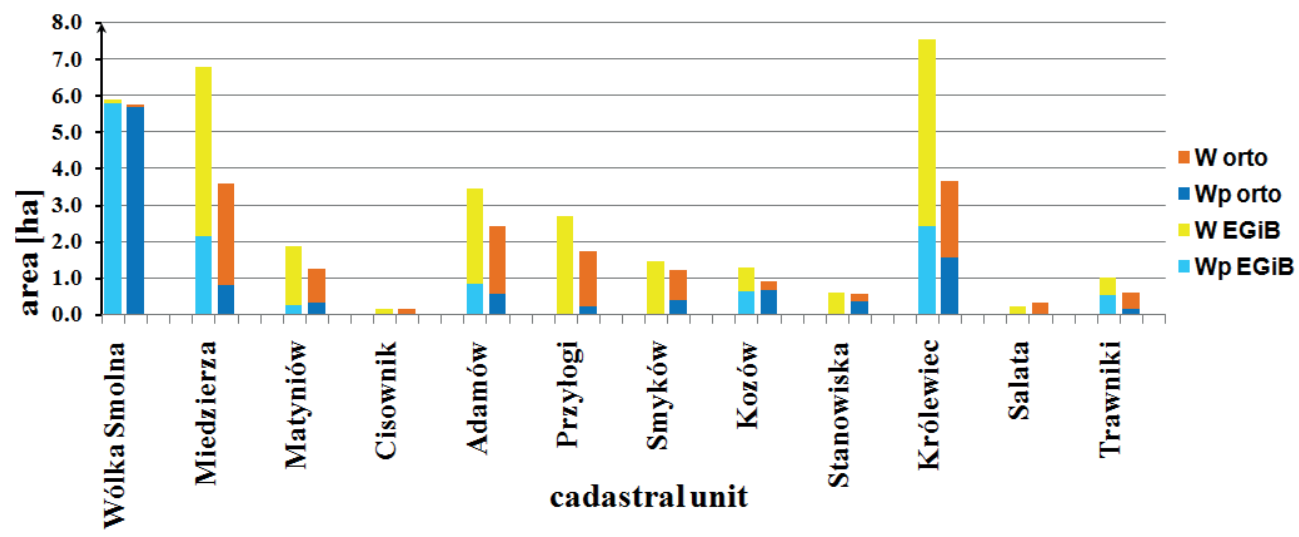

Fig. 9. Comparison of land area $W_{p}$ and $W$ in individual precincts registration 
In most precincts surface trenches shown in the records is much larger, it may indicate that the trenches shown in the records over time as a result of changes in land ceased to exist.

A deeper analysis of the chart can confirm also noticed on orthophotomap examples of incorrectly specified land. It can be seen in the case where the surface of the trenches disclosed in the records it is greater and at the same time the surface of flowing waters in the area is greater than that shown in the cadastre. The course in the record has been incorrectly marked as $W$, therefore the area of the ditch will be greater in the records and at the same time smaller in area. Surface water flowing in such cases, therefore, is larger in area than that shown in the cadastre. Such examples occur in FIVE precincts: Przyłogi, Smyków, Kozów, Stanowiska and Matyniów. It is possible, therefore, that in these precincts will be able to find examples of falsely labeled use $W$ in place of $W_{p}$.

In the next stage of the study made "intersection" of the vectorized land ( $W$ and $W_{p}$ ) on the basis of orthophotos and records in order to calculate the area of rivers and ditches, which corresponds to the same limits on orthophotomap and cadastral map. Then, in order to fully investigate the phenomenon, an author calculated percentage of the surface of overlapping (both in the cadastre and orthophotomap) to the total area shown in the database register of land and buildings. The results are shown on Figure 10.

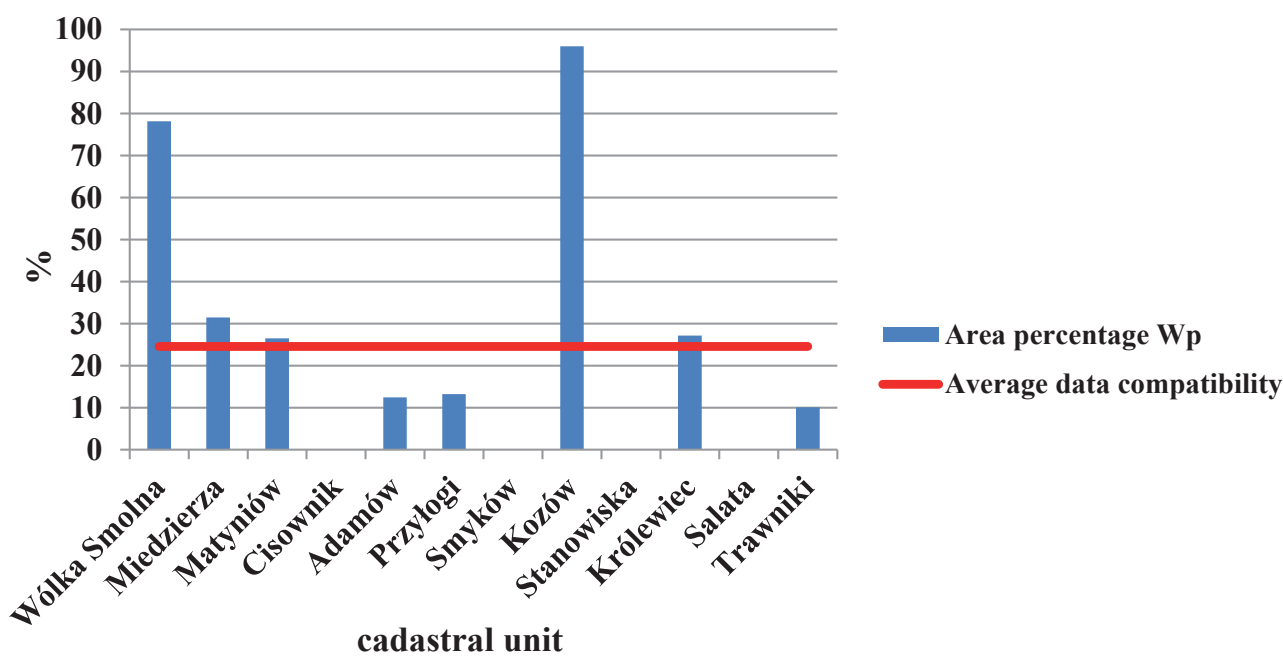

Fig. 10. Percentage of actual surface flowing waters covering the records

Figure 10 shows how data on the course of borders of rivers revealed in the register of land and buildings are in line with their actual course in the area. Average data compatibility was only $25 \%$. It is a very small percentage, and says explicitly that the data registration in the municipality Smyków are very little current. Only 2 cadastral units: Wólka Smolna and Kozów have a compliance higher than 50\%. Other cadastral 
units would be included in a process of modernization of land records. So little data consistency in the case of flowing water is very worrying, because the limits of use $W_{p}$ according to Polish law, determine the scope of property rights.

A similar process of calculation was also performed for the ditches. The calculation results are shown in Figure 11. As it can be seen covering the surface of the trenches in individual precincts is greater than the flowing waters. It can also be noticed a greater compliance with accounting data disclosed in the field. Average compliance data was $41 \%$.

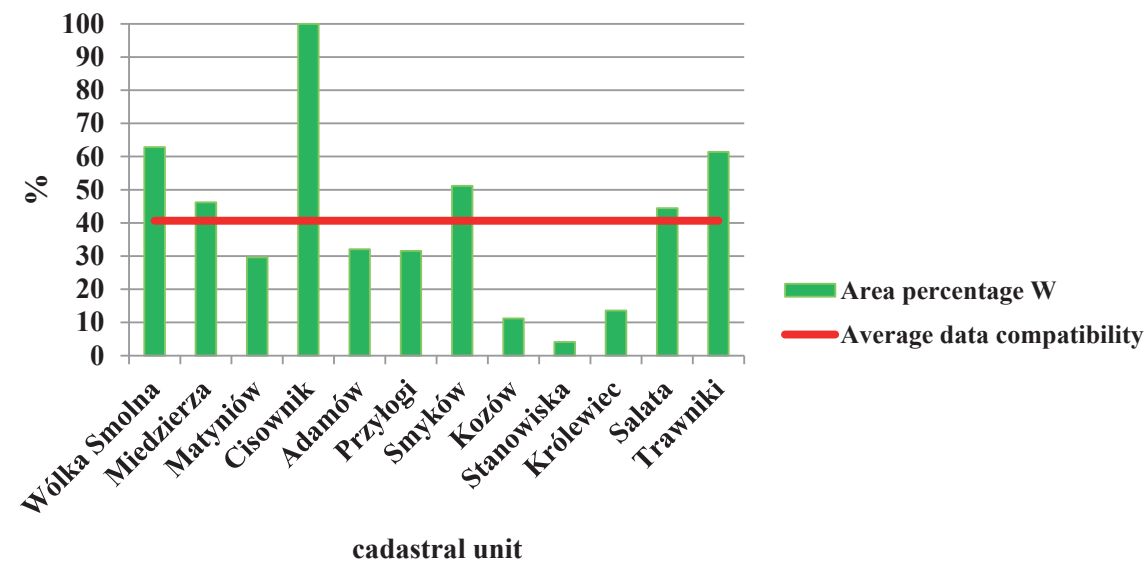

Fig. 11. Percentage of actual surface trenches covering the records

Figure 12 presents the data for the ditches and flowing waters. Coefficient of acceptability for data registration set at $50 \%$.

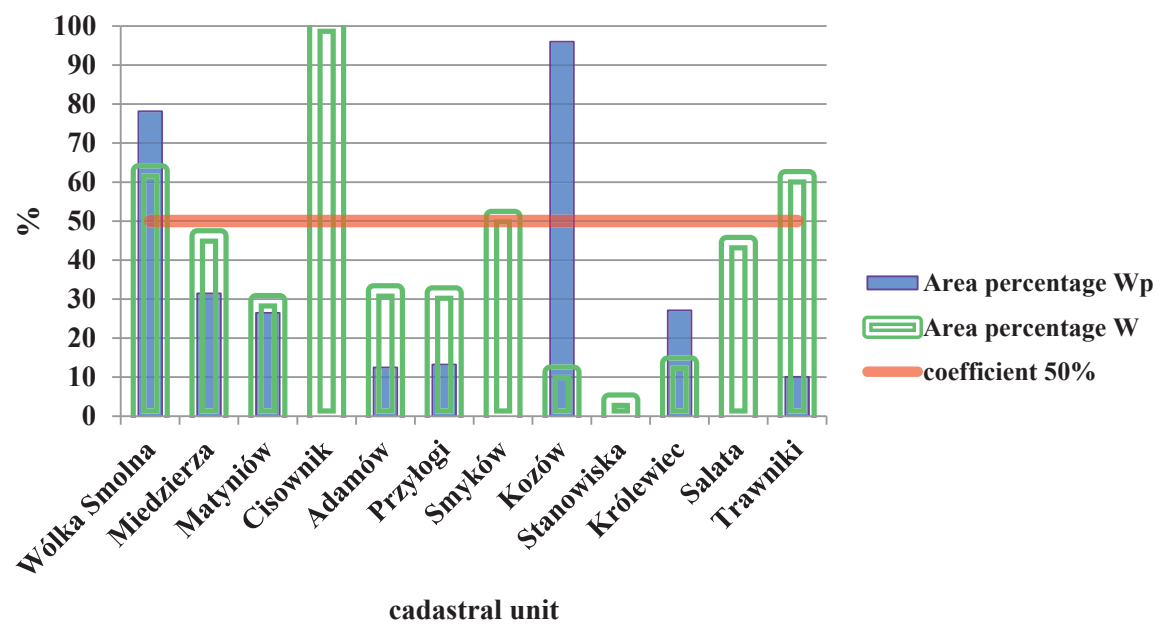

Fig. 12. Percentage of the actual surface of flowing waters and ditches covering the records 
As can be seen in only one cadastral unit, Wólka Smolna, the percentage of overlapping area $\mathrm{Wp}$ and $\mathrm{W}$ is greater than $50 \%$, so only the data registration for this unit are acceptable. In other cadastral units any of the land does not meet the criterion of $50 \%$.

On the basis of this chart it can be unequivocally stated that the data on the course of borders and ditches flowing water in the municipal area Smyków are outdated. To a very small extent they coincide with what can be observed in the field. It should be noted that they should be covered during the modernization process.

\section{Conclusions}

Analysis carried out using GIS tools explicitly confirmed what was observed comparing orthophotomap to the cadastral map.

The analyzes carried out, showed numerous examples of incorrectly specified land, many deficiencies of demonstration courses on maps registration. It was also noted that a greater length of watercourses natural shore line shown in the records does not coincide with the one actually that can be observed in the field. Watercourses have a natural ability to spontaneously change their course, very often naturally change their course, so it would be concluded that the boundaries of watercourses should be more frequently updated.

The correct delimitation of boundary of the ditches, and in particular of water flowing in the opinion of this author's work is very important, because the line the shore shown in land and buildings report directly affects the scope of ownership. Changing the shore line changes the boundaries of the property.

In carrying out the analysis there were noted examples disclose natural watercourses on the maps registration or exhibiting them as trenches. Undoubtedly, this is a big mistake, because it can result in the creation of the legal status inconsistent with reality.

It was also observed that instances do not maintain the continuity of watercourses on the border of cadastral units. Track was ended at the border of cadastral unit, not having him on the next sheet of the map. This is due to the fact that the cadastral units were drawn into separate map sheets.

After testing, it was found out that both comparative analysis of orthophotos with cadastral map, as well as spatial analyzes have shown that the registration of the boundaries of watercourses and ditches in the area of the municipality Smyków are outdated and in need of modernization.

The average compliance of the data defining the boundaries of disclosures in the land and buildings report from their actual occurrence in the area for flowing water was determined at 25\%, while the ditches at $41 \%$. Only in the case of cadastral unit, Wolka Smolna compliance data on land $W$ and in $W_{p}$ is greater than $50 \%$. 


\section{References}

[1] Bieda A., Bydłosz J., Parzych P.: Actualization of Data Concerning Surface Flowing Waters, Based on INSPIRE Directive Requirements. Geomatics and Environmental Engineering, vol. 7, no. 1, 2013, pp. 25-36.

[2] Bieda A., Parzych P.: Wptyw zmian linii brzegowych na konfiguracje granic ewidencyjnych. Studia i Materiały Towarzystwa Naukowego Nieruchomości, vol. 20, no. 4, 2012, pp. 67-76.

[3] Felcenloben D.: Ustalenie linii brzegowej wody ptynacej. Przegląd Geodezyjny, r. 84, nr 6, pp. 3-8.

[4] Główny Urząd Statystyczny: Mały Rocznik Statystyczny Polski. Zakład Wydawnictw Statystycznych, Warszawa, r. 57, 2014.

[5] Kowalski K.: Gospodarka nieruchomościami pokrytymi powierzchniowymi wodami płynacymi. Wrocław 2010, [on-line:] www.gruntiwoda.pl [accessed: 10.01.2016].

[6] Ustawa z dnia 18 lipca 2001 r. - Prawo wodne. Dz. U. 2001 nr 115, poz. 1229 z późn. zm. [Act of 18 July 2001 - Water Law. Journal of Laws of 2001, No. 115, item 1229 as amended].

[7] www.geoportal.gov.pl. 